\title{
Rare Structural Chromosomal Abnormalities in Prenatal Diagnosis; Clinical and Cytogenetic Findings on 10125 Prenatal Cases
}

\author{
Prenatal Tanıda Nadir Yapısal Kromozom Anomaliler; \\ 10125 Prenatal Olgunun Klinik ve Sitogenetik Bulguları
}

 \\ Sibel BERKER KARAÜZÜM ${ }^{1}$, Güven LÜLECi'
}

Department of 'Medical Biology and Genetics, ${ }^{2}$ Obstetrics and Gynecology and ${ }^{3}$ Pathology, Akdeniz University, School of Medicine, ANTALYA, TURKEY

\begin{abstract}
Objective: The aim of this study was presentation of the ultrasonographic findings and perinatal autopsy of cases with rare chromosomal abnormalities.
\end{abstract}

Material and Method: A total of 10125 prenatal cases over 17 years including 8731 amniocentesis, 973 chorionic villus sampling, and 421 fetal blood sampling cases were evaluated for prenatal cytogenetic diagnosis. Conventional cytogenetic studies, fluorescence in situ hybridization studies, and Array-CGH analysis techniques were used for genetic analysis.

Results: A structural chromosomal abnormality was observed in 95 cases. The most frequently observed structural abnormalities were balanced translocations with a frequency of $53.7 \%$ (51 cases) followed by unbalanced translocations (16.8\%), inversions (11.6\%), supernumerary marker chromosomes (8.4\%), duplications (4.2\%), deletions and ring chromosomes $(2.1 \%)$ and complex translocation (1.1\%). Rare structural chromosomal abnormalities including de novo balanced translocations, unbalanced translocations, inversions, duplications, deletions, ring chromosomes, and supernumerary marker chromosomes were detected in 24 cases.

Conclusion: The rate of rare chromosomal abnormalities varies from 2.4\% (South East Ireland) to 12.9\% (Northern England) in Europe with a total rate of 7.4/10 000 births. In our study, the overall rate of chromosomal abnormality in prenatal cytogenetic diagnosis was 3.7\%, similar to South East Ireland. Ultrasonographic and perinatal autopsy findings of the cases with rare structural chromosomal abnormalities are important for proper genetic counseling for further similar cases.

Key Words: Prenatal diagnosis, Cytogenetics, Chromosomal aberrations, Autopsy

\begin{abstract}
ÖZ
Amaç: Çalışmada nadir kromozomal anomalilerin ultrasonografik ve perinatal otopsi bulgularını sunmayı amaçladık.

Gereç ve Yöntem: Çalışmada 17 yıllık bir süreçte hastanemize prenatal sitogenetik değerlendirmeye gelen 10125 olguyu ele aldık. Olguların 8371'i amniyosentez, 973'ü koryonik villus örneklemesi ve 421'i fetal kan örneğinden oluşmaktadır. Genetik analiz için konvasiyonel sitogenetik yöntemler, floresan in situ hibridizasyon ve array-CGH teknikleri kullanılmıştır.

Bulgular: Yapısal kromozomal anomaliler 95 olguda görüldü. En sık görülen yapısal anomali grubunu $\% 53,7$ oranı (51 olgu) ile dengeli translokasyonlar oluşturmakta olup, bunu \%16,8 ile dengesiz translokasyonlar, \%11,6 ile inversiyonlar, \%8,4 ile ilave marker kromozomlar, \%4,2 ile duplikasyonlar, \%2,1 ile delesyon ve ring kromozomlar, \%1,1 ile kompleks translokasyonlar izlemektedir. De novo dengeli translokasyonlar, dengesiz translokasyonlar, inversiyonlar, duplikasyonlar, delesyonlar, ring kromozomlar ve ilave marker kromozomlardan oluşan nadir yapısal anomaliler 24 olguda tespit edilmiştir.
\end{abstract}

Sonuç: Nadir kromozomal anomalilerin oranları Avrupa'da \%2,9 (Güney Doğu İrlanda) ile \%12,9 (Kuzey İngiltere) arasında değişmektedir ve toplamda oran 7,4 / 10000 doğumdur. Çalışmada prenatal sitogenetik tanıda genel kromozomal anomali oranı \%37 olup, Güney Doğu İrlanda'ya benzerdir. Nadir yapısal kromozom anomalilerine sahip olguların prenatal ultrasonografik değerlendirmeleri ve perinatal otopsi sonuçları diğer benzer olgulara doğru genetik danışma vermek için oldukça önemlidir.

Anahtar Sözcükler: Prenatal tanı, Sitogenetik, Kromozomal anomaliler, Otopsi
(Turk Patoloji Derg 2015, 31:36-44)

Received : 30.06.2014 Accepted : 01.08.2014
Correspondence: Havva Serap TORU

Akdeniz Üniversitesi Tip Fakültesi, Patoloji Anabilim Dalı, ANTALYA, TURKEY

E-mail: serap_toru@yahoo.com Phone: +90 2422496000 


\section{INTRODUCTION}

Prenatal diagnosis with conventional cytogenetic analysis has been recognized for more than 30 years as a safe and reliable method for couples at increased risk of having a child with a clinically significant chromosomal abnormality (1). The application of prenatal diagnosis has been increased due to advances in screening maternal serum markers, ultrasonography, and increasing maternal age. Early detection of chromosomal abnormalities during pregnancy is important for proper genetic counseling and for management of informed decisions about continuing or terminating the pregnancy (2). Some of these numerical and structural chromosomal abnormalities are uncommon in prenatal diagnosis and correlations between these cytogenetic findings and ultrasonographic findings, clinical outcomes of the pregnancies and follow-up of the fetuses with these rare chromosomal abnormalities are very important to provide genetic counseling for further similar cases (3).

In this study, we report a single center experience of rare structural chromosomal abnormalities detected during prenatal diagnosis over 17 years and also the ultrasonographic and perinatal autopsy findings associated with rare chromosomal abnormalities that are very important for physicians and geneticists in proper genetic counseling.

\section{MATERIALS and METHODS}

Study Population: In this study, 8731 amniocentesis (AC), 973 chorionic villus (CVS) and 421 fetal blood samples representing 17 years of experience at Akdeniz University Hospital in Turkey were analyzed cytogenetically. The indications for prenatal karyotyping included advanced maternal age (>35), increased risk in double, triple or quadruple test screening, abnormal ultrasonographic finding, previous chromosomal abnormalities, family history of a previous child with chromosomal abnormality and others.

Conventional Cytogenetic Studies: The amniocytes and chorionic villus samples were cultivated in two or three different flasks containing $2 \mathrm{ml}$ AmnioGrow (Cytogen $\mathrm{GmbH}$, Bienenweg, Germany) and Chang Medium-D (Irvine scientific, Santa Ana, CA, USA) and fetal blood samples were cultivated using the short-term cell culture (72 hour) technique. Parents' karyotypes were also evaluated by using a standard method for G-banding (GTG) in order to determine whether the abnormality found in the fetus was de novo or inherited. If the fetus was found to have a chromosomal abnormality or a polymorphism, CBG and NOR banding analysis were applied for identification and characterization of abnormal chromosomes and polymorphisms. Karyotypes were described according to the International System for Human Cytogenetic Nomenclature (4). A minimum of 20 metaphases from two cultures were analyzed. Mosaicism was considered when the same abnormality was seen in more than two metaphases in two different cultures (5).

Fluorescence In Situ Hybridization (FISH) Studies: FISH tests were performed using Prader Willi/Angelman syndrome and Down Syndrome Critical region dual color locus specific probes (Aquarius ${ }^{\mathrm{TM}}$ probes-Cytocell'; Oxon; UK) according to the manufacturer's instructions. At least 15 metaphase plates were analyzed. FISH analysis using the Chromoprobe Multiprobe-I System (Cytocell, Rainbow Scientific, Inc., Windsor, CT) and SpectraVysion Multicolor FISH system (Vysis Inc, Downers Grove, Illinois, USA) were performed according to the manufacturer's instructions to detect the origin of the marker chromosomes. At least 5 metaphase plates were analysed from each square on the Multiprobe-I system and SpectraVysion Multicolor FISH system. Also, one hundred interphase nuclei were analysed from uncultured amniocytes by using centromeric probes in order to discriminate real mosaicisms from culture artifacts. Images were recorded using a Zeiss Axioplan epifluorescence microscope equipped with a CCD camera (Photometrics Sensys) and analysed using MacProbe v 4.3 software.

Array-CGH Analysis: Array-CGH analysis were performed using genomic DNA samples obtained from amniocytes of the cases, according to the manufacturer's protocol for Cytogenetics Whole Genome 2,7 M oligonucleotide catalog array (Affymetrix Inc., Santa Clara, CA, USA). The microarray image data were scanned by GeneChip ${ }^{\circ}$ 7G High Resolution Scanner using the Command Console software (Affymetrix Inc., Santa Clara, CA, USA). Data were analyzed using the Chromosome Analysis Suit Version 1.0 (Affymetrix Inc., Santa Clara, CA, USA).

\section{RESULTS}

During 17 years, 10125 prenatal cases including 8731 AC, 973 CVS, and 421 fetal blood samples were evaluated for prenatal cytogenetic diagnosis. The number of CVS samples significantly increased in recent years. The rate of culture failure, due to cell culture growing problems, microbial contaminations and unsuitable/insufficient material was $0.67 \%$. Culture failure was observed mostly in CVS material but significantly decreased through the years. The overall culture success rate was $99.33 \%$. The overall rate of chromosomal abnormality in prenatal cytogenetic diagnosis was $3.7 \%$. 
All chromosome abnormalities were classified into the following categories: numerical abnormalities (autosome and sex chromosomes), balanced translocations, unbalanced translocations, inversions, supernumerary marker chromosomes, deletions, duplications, complex rearrangements and ring chromosomes. Heterochromatin variations of the chromosomes 1, 9, 16 and $\mathrm{Y}$ and nucleolus organizer regions of chromosomes of D and $\mathrm{G}$ group were not reported.

In our cohort, 8 cases with de novo balanced reciprocal translocations were observed. Case 1 with $\mathrm{t}(4 ; 15)(\mathrm{q} 23 ; \mathrm{q} 26,1)$ de novo balanced reciprocal translocation, cystic hygroma and hydrops fetalis was detected with USG abnormalities. Case 2 with de novo $t(2 ; 7)(\mathrm{p} 21 ; \mathrm{p} 22)$ balanced reciprocal translocation had unilateral radial club hand, radius aplasia, ulnar hipoplasia and thumb hipoplasia as ultrasonographic findings. These balanced reciprocal translocations in conjunction with the ultrasonographic findings have rarely been reported. After genetic counseling, the pregnancies were terminated according to the parents' requests in both cases. Postmortem evaluations revealed facial abnormalities, cystic hygroma, hydrops fetalis and bilateral ventricular dilatation in case 1. Facial abnormalities, forearm and hand malformations were observed during postmortem evaluations of case 2 (Figure 1).

In case 3, co-existence of 6q25.3-qter monosomy and $18 \mathrm{q} 21.3$ trisomy due to de novo unbalanced translocation between chromosomes 6 and 18 was detected in association with bilateral ventriculomegaly and choroid plexus cysts as ultrasonographic abnormalities.

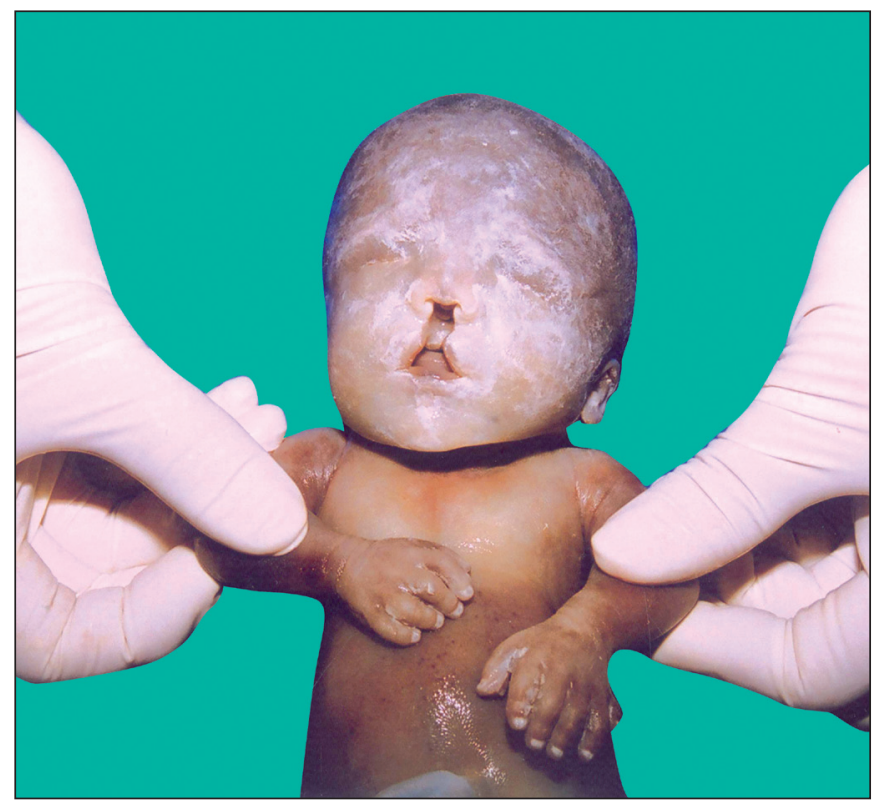

Figure 1: Fetus with cleft lip and palate, low-set ears, depressed nasal bridge, radial club hand, radius aplasia, ulnar hypoplasia, thumb hypoplasia (Case 2).
In case 4 , monosomy of the 18p11-pter region due to de novo unbalanced translocation between 13p11.1 and 18p11 chromosome bands was detected in association with bilateral ventricular dilatation. In case 5 , monosomy $18 \mathrm{p}$ due to de novo unbalanced translocation between chromosomes 18 and 22 along with increased nuchal transluency was observed prenatally. Case 6 had unbalanced translocation resulted with 6q25 monosomy and associated with bilateral ventriculomegaly.

In the case 7, de novo 46,XY,der(15)t(15;18)(q13.1;p11.2) unbalanced translocation resulted in partial monosomy of the chromosome 15q13.1-qter and partial trisomy of chromosome 18p11.2-pter and oligohydramnios was detected as the ultrasonographic finding. Micrognathia, low-set ears, down-slanting palpebral fissures, flexion deformity on right hand, rocker-bottom foot were detected on postmortem evaulation.

We found 11 cases with pericentric inversions of chromosomes 3,12,17, Y and paracentric inversions of the chromosomes 6,10 and 14. Five of eleven cases had rare forms of inversions such as $\operatorname{inv}(12)(\mathrm{p} 11.22 \mathrm{q} 13.13)$ pat, $\operatorname{inv}(12)(\mathrm{p} 11.22 \mathrm{q} 13.1) \mathrm{mat}, \quad \operatorname{inv}(3)(\mathrm{p} 21.3 \mathrm{q} 12) \mathrm{mat}, \quad \operatorname{inv}(10)$ (q11.2q23.2)pat and inv(6)(q25.1q25.3)pat inversions. Ultrasonographic screenings did not reveal any fetal abnormalities in these five cases. After the genetic counseling, all of the five families decided to carry the pregnancy to term. The follow-up evaluations of the babies were normal.

We have observed rare euchromatin variants in three cases leading to duplications of 9p11.21-13.1, 9q13-21.12, 15q11-13 chromosome regions. 15q11q13 duplications were maternally transmitted to the fetus and FISH results using Prader Willi/Angelman syndrome dual color locus specific probes showed that duplicated region did not contain the PWS/AS critical region. We found two prenatal cases with maternally inherited duplications of chromosome 9p11.2-p13.1 and 9q13-q21.12. Duplication of the 9p11.2-p13.1 region in case 21 was confirmed by array CGH analysis.

We observed de novo interstitial deletion of the 5q13-q22 and 1q22-q25 chromosome regions in case 18 and 19 who were referred for amniocentesis due to increased nuchal transluency and bilateral pyelectasis, respectively. In both cases the pregnancies were terminated due to the abnormal cytogenetic findings. Postmortem evaluations of case 18 revealed facial abnormalities, broad neck, posterolateral diaphragmatic hernia, bilateral club foot, unilateral kidney agenesis, and thymic dysplasia. Facial abnormalities, flexion deformity on hands and feet and cardiomegaly were observed during postmortem evaluations in case 19. 
We detected eight supernumerary marker chromosomes in our cohort with a frequency of $0.079 \%$. In five of these cases, the chromosomal origins of the marker chromosomes were clarified by FISH using Chromoprobe Multiprobe-I and SpectraVysion Multicolor FISH probes. In two of the cases, supernumarary marker chromosomes originated from chromosome 15 and the other one was from chromosome 13 or 21 . In the remaining three cases, the families did not accept further molecular cytogenetic studies for the detection of the origin of supernumerary marker chromosomes.

In case 23 with de novo mosaic ring chromosome 13, breakpoints were located at p11 and q32 bands. Prenatal cytogenetic analyses were performed because of multiple ultrasonographic findings. The pregnancy was terminated. However, the details of the ultrasonographic findings and postmortem evaluations were not available.

We detected de novo ring chromosome 21 in one case. Possible duplication or deletion of the Down syndrome on the critical region of the ring chromosome 21 was excluded by FISH analysis using Down Syndrome Critical region dual color locus specific probes. Genetic counseling was given to parents considering the existence of monosomy 21 mosaicism. The family decided to terminate the pregnancy.

Structural abnormalities were observed in 95 cases. The most frequent structural abnormalities were balanced translocations with a frequency of $53.7 \%$ (51 cases) followed by unbalanced translocations (16.8\%), inversions (11.6\%), supernumerary marker chromosomes (8.4\%), duplications (4.2\%), deletions and ring chromosomes
(2.1\%) and complex translocation (1.1\%) (Table I). Familial transmission status of the structural chromosomal abnormalities was as follows; de novo in 47 cases (49.5\%), maternal in 30 cases (31.6\%), and paternal in 18 cases (18.9\%). Mosaicism was not detected in 83 of 95 cases with a structural chromosomal abnormality (87.4\%), whereas in 12 cases, structural chromosome abnormalities were in a mosaic state (12.6\%). Rare chromosomal abnormalities and the clinical details of these fetuses are presented in Table II.

\section{DISCUSSION}

We presented here rare cases with balanced translocations associated with USG findings, unbalanced translocations, inversions, duplications / rare euchromatin variants, deletions, supernumerary marker chromosomes and ring chromosomes.

In newborn studies, the rate of chromosomal abnormalities is 17-31/10.000 births (6-7). The chromosomal abnormality rate in misscarried or stillbirth fetuses is $43.6 / 10.000$ births (8). As expected the rate of chromosomal abnormalities varies between prenatal and postnatal sources. The rate of rare chromosomal abnormalities varies from 2.4\% (South East Ireland) to $12.9 \%$ (Northern England) in Europe with the total rate of 7.4/10 000 births (8). In our study the overall rate of chromosomal abnormality in prenatal cytogenetic diagnosis was 3.7\%, similar to South East Ireland in Europe.

Balanced translocations; It has been accepted that familial balanced translocations detected by prenatal diagnosis are not associated with phenotypical abnormalities (9). However, in $6 \%$ of the prenatally detected de novo balanced reciprocal translocations have been associated with a risk

Table I: Frequencies of structural chromosomal aberrations

\begin{tabular}{|l|c|c|}
\hline Karyotypes & Number of cases & Percentage of cases (\%) \\
\hline Total structural rearrangements & $\mathbf{9 5}$ & 100 \\
\hline 1. Balanced translocations & 51 & 53.7 \\
\hline 1.a) Reciprocal translocation & 29 & 30.5 \\
\hline - Autosome-autosome type & 28 & \\
\hline - Sex chromosome-autosome type & 1 & 23.2 \\
\hline 1.b) Robertsonian translocation & 22 & 16.8 \\
\hline 2. Unbalanced translocations & 16 & 11.6 \\
\hline 3. Inversion & 11 & 8.4 \\
\hline 4. Supernumerary marker chromosome & 8 & 2.1 \\
\hline 5. Deletion & 2 & 4.2 \\
\hline 6. Duplication & 4 & 1.1 \\
\hline 7. Complex rearrangement & 1 & 2.1 \\
\hline 8. Ring chromosome & 2 & \\
\hline
\end{tabular}









\begin{tabular}{|c|c|c|c|c|c|c|c|c|c|c|c|}
\hline ' & ' & ' & 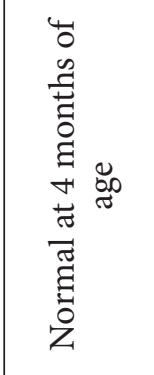 &  & 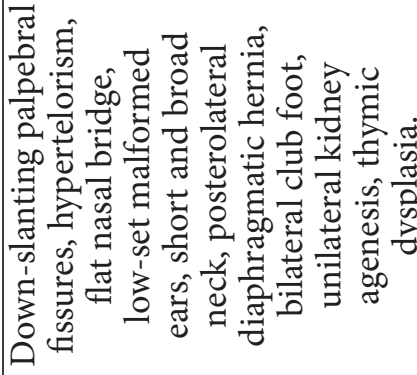 & 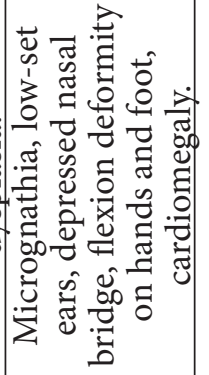 &  & 1 & ' &  & 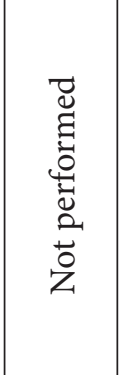 \\
\hline  & 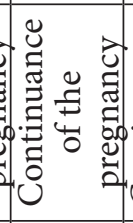 &  &  &  & oี & $\underset{\mathrm{o}}{0}$ & 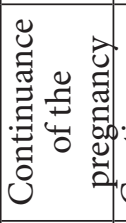 &  & 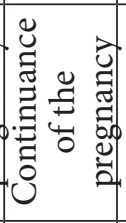 & 0 & $\stackrel{0}{0}$ \\
\hline  & 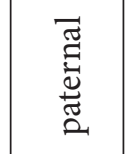 & 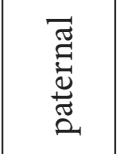 &  & 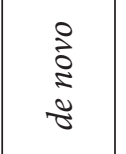 &  & 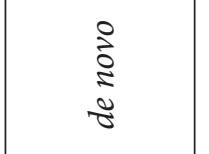 & 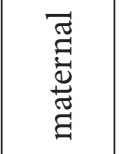 & 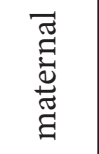 & 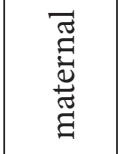 &  & 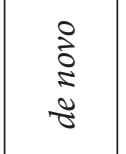 \\
\hline $\begin{array}{l}\overline{\widetilde{\Xi}} \\
\text { है } \\
\text { z }\end{array}$ & $\begin{array}{l}\overline{\widetilde{\Xi}} \\
\text { है } \\
\text { z }\end{array}$ & 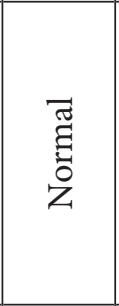 & $\begin{array}{l}\overline{\widetilde{\Xi}} \\
\tilde{\Xi} \\
z\end{array}$ & $\begin{array}{l}\bar{\Xi} \\
\tilde{\Xi} \\
\text { z }\end{array}$ & 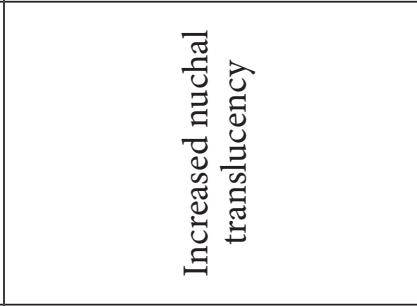 & 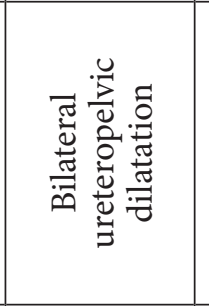 & 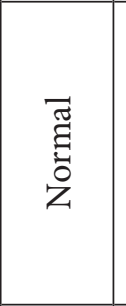 &  & $\begin{array}{l}\bar{\Xi} \\
\tilde{\Xi} \\
\text { z }\end{array}$ & 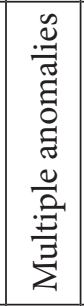 & 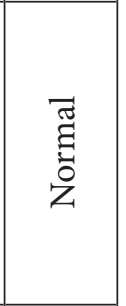 \\
\hline 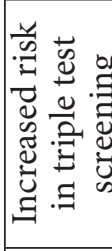 &  & 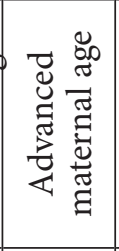 & 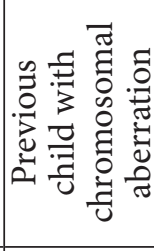 & 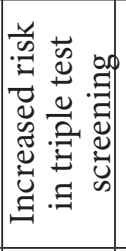 & 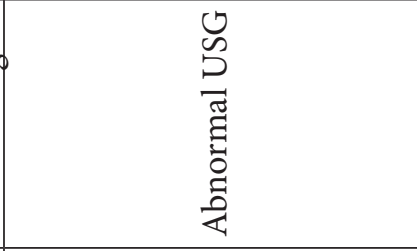 & $\begin{array}{l}0 \\
0 \\
0 \\
\text { चี } \\
\text { है } \\
0 \\
0 \\
\text { : }\end{array}$ & 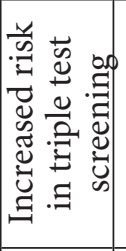 & 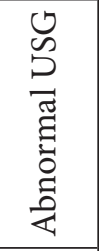 & 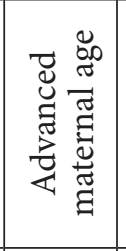 & 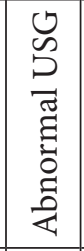 &  \\
\hline 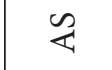 & $\sum_{4}^{\infty}$ &  &  & 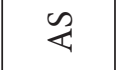 & $\&$ & 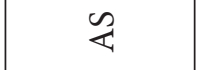 &  &  & 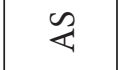 &  &  \\
\hline$\stackrel{0}{0}$ & $\bumpeq$ & 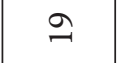 & $\stackrel{\infty}{=}$ & $\stackrel{\infty}{-}$ & $\stackrel{0}{\sim}$ & $\widetilde{\sim}$ & 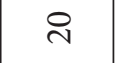 & ‡ి & $\beth$ &  & $\vec{\sim}$ \\
\hline$\stackrel{\leftrightarrow}{\sim}$ & $\stackrel{\infty}{\sim}$ & 구 & $\underset{\sim}{\sim}$ & $\hat{m}$ & $\hat{\sim}$ & $\widehat{\curvearrowright}$ & $\stackrel{\sim}{\sim}$ & 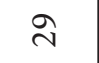 & i & i & $\hat{\sim}$ \\
\hline  & 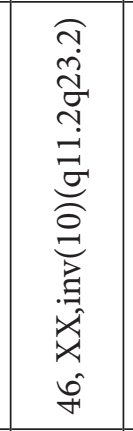 &  &  & 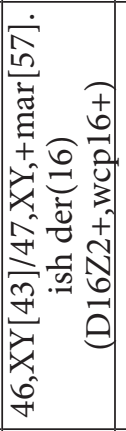 &  & 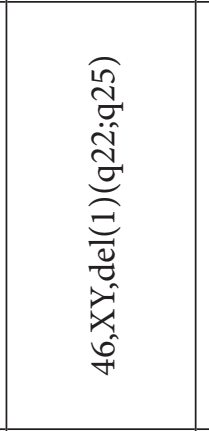 & 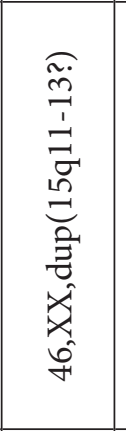 & 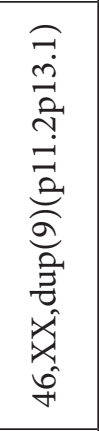 & 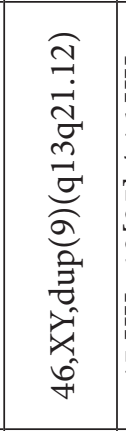 & 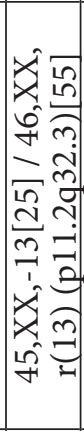 & 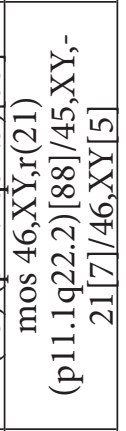 \\
\hline$\stackrel{m}{=}$ & $\Xi$ & $\stackrel{n}{=}$ & $\stackrel{0}{=}$ & $\cong$ & $\stackrel{\infty}{=}$ & 9 & ટ્ & $\vec{\sim}$ &  & $\ddot{\sim}$ & $\stackrel{\sim}{\sim}$ \\
\hline
\end{tabular}


of important congenital abnormalities (10). Congenital malformations in apparently balanced translocations might resulted microdeletions or gene disruption at the breakpoints or formation of a new rearrangement that leads to a altered gene function (10). In our cohort, cases with de novo balanced reciprocal translocations had several anomalies. Detailed USG and follow-up evaluations should be performed prenatally in cases with an apparently balanced translocation.

Unbalanced Translocations; There is no report on a prenatal case with choroid plexus cysts and 6q25.3-qter monosomy or 18q21.3 trisomy. Previous reports on postnatal cases indicate that enlargement in lateral ventricles can be observed in cases with 6q25 monosomy $(11,12)$. Our case is the first prenatally evaluated case showing an association between $6 \mathrm{q} 25$ monosomy and bilateral ventriculomegaly. Chromosome 6q25-qter region must therefore be kept in cases with bilateral ventriculomegaly as an ultrasonographic finding.

Several reports on prenatally detected pure and complete monosomy $18 \mathrm{p}$ due to unbalanced translocations between chromosome 18 and acrocentric chromosomes have been previously published. In these cases, prenatal ultrasonographic findings including increased nuchal translucency thickness and holoprosencephaly were evident (13-17). In monosomy 18p, supraorbital flatness, depressed nasal bridge, flared nostrils and low-set ears were observed during postmortem evaluations (18). However, case 4 is the first prenatal case with pure and complete monosomy $18 \mathrm{p}$ presenting with bilateral ventricular dilatation as the only ultrasonographic finding. Postmortem evaluations showed; micrognathia, depressed nasal bridge and hypoplasia of lung and kidney.

Inversions; Chromosome 2 displays the highest frequency for pericentric inversion, while chromosome 3 and 7 are most often involved in paracentric inversions (19). To the best of our knowledge, $\operatorname{inv}(12)(\mathrm{p} 11.22 \mathrm{q} 13.13)$ pat, $\operatorname{inv}(12)(\mathrm{p} 11.22 \mathrm{q} 13.1) \mathrm{mat}, \operatorname{inv}(3)(\mathrm{p} 21.3 \mathrm{q} 12) \mathrm{mat}, \operatorname{inv}(10)$ (q11.2q23.2)pat and inv(6)(q25.1q25.3)pat inversions have not been reported previously in prenatal diagnosis.

Duplications/ Rare Euchromatin Variants; 15q11q13 duplications can be observed in clinically normal individuals and also in affected patients depending on the presence of the PWS/AS critical region (20). In our case, duplication was maternally transmitted to the fetus and the duplicated region did not contain the PWS/AS critical region. Cases with $\operatorname{dup}(15)(\mathrm{q} 11 \mathrm{q} 13)$ are rarely reported in prenatal cases and the previous reported five fetuses were born and were phenotypically normal (21). To our knowledge, our case is the sixth fetus with familial dup(15) (q11q13) prenatally detected. Genetic counseling was given to parents according to the literature and the family decided to continue the pregnancy that resulted in normal pregnancy outcome. Duplications of chromosome 9p11.2-p13.1 and 9q13-q21.12 have been previously reported as uncommon euchromatin variants that are associated with a normal phenotype (22). In both of our cases the pregnancies were continued to term and the babies were born without any clinical abnormality.

Deletions; In the literature, $4.7 \%$ of 11 chromosomal abnormalities were deletions (8). In contrast to the literature, only $2 \%$ of all were deletions in our study. Interstitial deletions in chromosomes 1 and 5 are rarely reported $(23,24)$. To our knowledge, interstitial deletions of $5 \mathrm{q} 13-\mathrm{q} 22$ and 1q22-q25 chromosome regions in prenatal diagnosis were observed for first time in our study.

Supernumerary Marker Chromosomes; Marker chromosomes are supernumerary structurally abnormal chromosomes with unknown origin, and might be found with a frequency of $0.075 \%$ and $0.044 \%$ in prenatal and postnatal diagnosis, respectively (25). Most of the supernumerary marker chromosomes originate from acrocentric chromosomes according to the literature. However, marker chromosomes originating from certain human chromosomes such as supernumerary marker chromosomes derived from chromosome 16 and 17 are rare. As we previously reported, our case with marker chromosome that originated from chromosome 16 is the third phenotypically normal case and had been followed-up until 7 months of age (26). Also, as we previously discussed, the case with supernumerary marker chromosome that originated from chromosome 17 is the second prenatally detected case continued to term and the follow-up revealed no clinical findings $(27,28)$.

Ring Chromosomes; De novo mosaic ring chromosome 13 breakpoints were located at the p1 1 and q32 bands. To our knowledge only one prenatal case has been reported. Chen et al., (2001) reported intrauterine growth retardation, a widely open mouth and absence of the cranial vault as ultrasonographic findings. Post mortem evaluations revealed anencephaly, hypertelorism, large low-set ears, micrognathia, retroflexed hands and feet without hypoplastic aplastic thumbs and toes (29). We had one case with prenatally detected USG abnormalities.

Ring chromosome 21 is a rare chromosomal abnormality often associated with mental retardation and dysmorphic features (30-33). Less commonly, the ring chromosome can 
be familial and associated with a normal phenotype but at increased risk of having children with Down syndrome $(34,35)$. We had one case with de novo ring chromosome 21.

In conclusion, detection of rare chromosomal abnormalities associated with ultrasonographic and perinatal autopsy findings are very important for physicians and geneticists for proper genetic counseling.

Funding Source: This study was supported by the Akdeniz University Scientific Research Project Management Unit.

\section{REFERENCES}

1. Dallaire L. Integration of prenatal diagnosis of genetic diseases into medical practice. Can Med Assoc J. 1976;115:713-4.

2. Stembalska A, Slezak R, Pesz K, Gil J, Sasiadek M. Prenatal diagnosis-principles of diagnostic procedures and genetic counseling. Folia Histochem Cytobiol. 2007;45 Suppl 1:S11-6.

3. Baena N, De Vigan C, Cariati E, Clementi M, Stoll C, Caballin MR, Guitart M; EUROSCAN Working Group. Prenatal detection of rare chromosomal autosomal abnormalities in Europe. Am J Med Genet A. 2003;118A:319-27.

4. An international system for human cytogenetic nomenclature. Shaffer LG, Slovak ML, Campbell LJ, editors. Basel: Karger Press; 2009.

5. Chromosome abnormalities and genetic counseling. 4th ed. Gardner RJM, Sutherland GR, Shaffer LG, editors. New York: Oxford University Press; 2011.

6. Hamerton JL, Canning N, Ray M, Smith S. A cytogenetic survey of 14,069 newborn infants. I. Incidence of chromosome abnormalities. Clin Genet. 1975;8:223-43.

7. Dolk H, Loane M, Garne E. The prevalence of congenital anomalies in Europe. Adv Exp Med Biol. 2010;686:349-64.

8. Wellesley D, Dolk H, Boyd PA, Greenlees R, Haeusler M, Nelen V, Garne E, Khoshnood B, Doray B, Rissmann A, Mullaney C, Calzolari E, Bakker M, Salvador J, Addor MC, Draper E, Rankin J, Tucker D. Rare chromosome abnormalities, prevalence and prenatal diagnosis rates from population-based congenital anomaly registers in Europe. Eur J Hum Genet. 2012;20:521-6.

9. Chen CP, Wu PC, Lin CJ, Su YN, Chern SR, Tsai FJ, Lee CC, Town DD, Chen WL, Chen LF, Lee MS, Pan CW, Wang W. Balanced reciprocal translocations detected at amniocentesis. Taiwan J Obstet Gynecol. 2010;49:455-67.

10. Warburton D. De novo balanced chromosome rearrangements and extra marker chromosomes identified at prenatal diagnosis: Clinical significance and distribution of breakpoints. Am J Hum Genet. 1991;49:995-1013.

11. Koh S, Boles RG. Cerebral aqueductal stenosis as a presentation of deletion 6q25-qter. Clin Genet. 1998;53:317-8.

12. CavaniS, Perfumo C, Faravelli F, Malacarne M, Sogliani M, Piombo G, Zerega G, Zucca M, Dagna Bricarelli F, Pierluigi M. Cryptic 1p36.3/6q25.2 translocation in three generations ascertained through a foetus with IUGR and cerebral malformations. Prenat Diagn. 2003;23:819-23.
13. Sepulveda W. Monosomy 18p presenting with holoprosencephaly and increased nuchal translucency in the first trimester: Report of 2 cases. J Ultrasound Med. 2009;28:1077-80.

14. Agarwal S, Oppenheimer CA, Howarth ES, Khare MM. A case of monosomy $18 \mathrm{p}$ diagnosed on the basis of an isolated finding of increased nuchal fold thickness. J Obstet Gynaecol. 2009;29:5489.

15. Edwards S, Waters JJ. Prenatal diagnosis of monosomy $18 \mathrm{p}$ involving a jumping translocation. Prenat Diagn. 2008;28:764-6.

16. Kim YM, Cho EH, Kim JM, Lee MH, Park SY, Ryu HM. Del(18p) syndrome with increased nuchal translucency in prenatal diagnosis. Prenat Diagn. 2004;24:161-4.

17. McGhee EM, Qu Y, Wohlferd MM, Goldberg JD, Norton ME, Cotter PD. Prenatal diagnosis and characterization of an unbalanced whole arm translocation resulting in monosomy for 18p. Clin Genet. 2001;59:274-8.

18. Yakut S, Simsek M, Pestereli HE, Baumer A, Luleci G, Schinzel A. Del (18p) syndrome with increased nuchal translucency revealed in prenatal diagnosis. Genet Couns. 2011;22:317-9.

19. Muss B, Schwanitz G. Characterization of inversions as a type of structural chromosome aberration. Int J Hum Genet. 2007;7:14161.

20. Ludowese CJ, Thompson KJ, Sekhon GS, Pauli RM. Absence of predictable phenotypic expression in proximal 15q duplications. Clin Genet. 1991;40:194-201.

21. Browne CE, Dennis NR, Maher E, Long FL, Nicholson JC, Sillibourne J, Barber JC. Inherited interstitial duplications of proximal 15q: genotype-phenotype correlations. Am J Hum Genet. 1997;61:1342-52.

22. Di Giacomo MC, Cesarano C, Bukvic N, Manisali E, Guanti G, Susca F. Duplication of 9 p11.2-p13.1: A benign cytogenetic variant. Prenat Diagn. 2004;24:619-22.

23. Malan V, Martinovic J, Sanlaville D, Caillat S, Waill MC, Ganne ML, Tantau J, Attie-Bitach T, Vekemans M, Morichon-Delvallez N. Molecular characterisation of a prenatally diagnosed $5 q 15 q 21.3$ deletion and review of the literature. Prenat Diagn. 2006;26:231-8.

24. Descartes M, Hain JZ, Conklin M, Franklin J, Mikhail FM, Lachman RS, Nolet S, Messiaen LM. Molecular characterization of a patient with an interstitial 1q deletion [del(1)(q24.1q25.3)] and distinctive skeletal abnormalities. Am J Med Genet A. 2008;146A:2937-43.

25. Liehr T, Mrasek K, Hinreiner S, Reich D, Ewers E, Bartels I, Seidel J, Emmanuil N, Petesen M, Polityko A, Dufke A, Iourov I, Trifonov V, Vermeesch J, Weise A. Small supernumerary marker chromosomes (sSMC) in patients with a 45,X/46,X,+mar karyotype - 17 new cases and a review of the literature. Sex Dev. 2007;1:353-62.

26. Yakut S, Cetin Z, Simsek M, Karauzum SB, Tukun A, Luleci G. Prenatal diagnosis of a de novo supernumerary marker chromosome originating from chromosome 16. Genet Couns. 2009;20:327-32.

27. Liehr T. Small supernumerary marker chromosomes (sSMCs): A spotlight on some nomenclature problems. J Histochem Cytochem. 2009;57: 991-3. 
28. Yakut S, Cetin Z, Berker-Karauzum S, Mihci E, Mendilcioglu I, Luleci G. De novo supernumerary marker chromosome originating from chromosome 17 resulting in a normal pregnancy outcome. Genet Couns. 2011;22:63-8.

29. Chen CP, Chern SR, Lee CC, Chen WL, Wang W. Prenatal diagnosis of mosaic ring chromosome 13 with anencephaly. Prenat Diagn. 2001;21:102-5.

30. Guilherme R, Klein E, Hamid A, Bhatt S, Volleth M, Polityko A, Kulpanovich A, Dufke A, Albrecht B, Morlot S, Brecevic L, Petersen M, Manolakos E, Kosyakova N, Liehr T. Human ring chromosomes - New insights for their clinical significance. Balkan J Med Genet. 2013;16:13-20.

31. Siragusa M, Lentini M, Schepis C. Agminated lentiginosis in a patient with ring chromosome 21. Eur J Dermatol. 2012;22:801-3.

32. Arslan M, Yis U, Vurucu S, Tunca Y, Unay B, Akin R. Ring chromosome 21 in the differential diagnosis of waddling gait. Brain Dev. 2012;34:792-5.
33. Chen CP, Lin YH, Chou SY, Su YN, Chern SR, Chen YT, Town DD, Chen WL, Wang W. Mosaic ring chromosome 21, monosomy 21, and isodicentric ring chromosome 21: Prenatal diagnosis, molecular cytogenetic characterization, and association with 2-Mb deletion of 21q21.1-q21.2 and 5-Mb deletion of 21q22.3. Taiwan J Obstet Gynecol. 2012;51:71-6.

34. Richer CL, Fitch N, Sitahal S, Murer-Orlando M, Jean P. Analysis of banding patterns in a case of ring chromosome 21. Am J Med Genet. 1981;10:323-31.

35. Melnyk AR, Ahmed I, Taylor JC. Prenatal diagnosis of familial ring 21 chromosome. Prenat Diagn. 1995;15:269-73. 